\title{
PENINDAKAN HUKUM TERHADAP PELANGGAN DAN PEKERJA SEKS KOMERSIAL
}

\author{
Oleh : \\ Selvidiyanti Harefa ${ }^{1)}$, \\ Suriani ${ }^{2)}$, \\ Ismail $^{3)}$ \\ Universitas Asahan ${ }^{1,2,3)}$ \\ E-mail: \\ selvihareva@gmail.com ${ }^{1)}$, \\ $\frac{\text { surianisiagian02@gmail.com }^{2)}}{\text { ismail_izu@yahoo.com }^{3)}}$,
}

\begin{abstract}
Prostitution is a fundamental structural problem that occurs in society because it is still understood as a moral problem. Provisions related to prostitution are regulated in the Criminal Code (KUHP), namely Article 296 and Article 506. It can be seen that criminal law only categorizes prostitution as a criminal act against its intermediaries (Pimp or Pimp). Whereas in cracking down on Customers and Commercial Sex Workers not in the Criminal Code specifically regulates it, a legal vacuum occurs. In this paper, a normative research method was used with the problem approach is the statutory approach. The problem raised in this paper is how the categories of perpetrators in commercial sex activities and how legal action in dealing with customers and commercial sex workers. Based on this, it can be concluded that the regulations governing law enforcement against customers and commercial sex workers are regulated based on the respective regional regulations in each region.
\end{abstract}

Keywords: Legal Arrangement, Prostitution, Commercial Sex Workers

\begin{abstract}
ABSTRAK
Prostitusi adalah masalah struktural mendasar yang terjadi di masyarakat karena masih dipahami sebagai masalah moral. Ketentuan terkait pelacuran diatur dalam KUHP, yaitu Pasal 296 dan Pasal 506. Dapat dilihat bahwa hukum pidana hanya mengkategorikan pelacuran sebagai tindak pidana terhadap perantara (Pimp atau Pimp). Sedangkan dalam menindak Pelanggan dan Pekerja Seks Komersial tidak dalam KUHP secara khusus mengaturnya, kekosongan hukum terjadi. Dalam tulisan ini, metode penelitian normatif yang digunakan dengan pendekatan masalah adalah pendekatan hukum. Masalah yang diangkat dalam makalah ini adalah bagaimana kategori pelaku dalam kegiatan seks komersial dan bagaimana tindakan hukum dalam berurusan dengan pelanggan dan pekerja seks komersial. Berdasarkan hal ini, dapat disimpulkan bahwa peraturan yang mengatur penegakan hukum terhadap pelanggan dan pekerja seks komersial diatur berdasarkan peraturan daerah masing-masing di masing-masing daerah.
\end{abstract}

Kata kunci: Pengaturan Hukum, Prostitusi, Pekerja Seks Komersial 


\section{PENDAHULUAN}

Prostitusi/pelacuran adalah salah satu permasalahan hukum yang sering terjadi dalam kehidupan sosial masyarakat saat ini, sebab hal ini merupakan salah satu permasalahan moral seseorang (Elizabert Pisani, 2008:69). Prostitusi atau pelacuran merupakan masalah sosial dan masalah hukum saat ini apabila kita melihatnya dari hubungan sebab akibat yang ditimbulkan dan asal mula dari prostitusi/pelacuran tidak dapat di deteksi dengan pasti adanya, namun sampai saat ini prostitusi/pelacuran masih banyak terjadididalam kehidupan sehari-hari baik itu secara individu atau perkelompok dan bisa dikatakan bahwa hampir di setiap wilayah di Indonesia, baik yang dilakukan secara terang-terangan maupun sembunyi-sembunyi dalam melakukannya (Hull., all, 1997:42).

Ketentuan hukum terkait mengenai prostitusi diatur dalam Kitab UndangUndang Hukum Pidana (KUHP) yakni dalam pasal 296 dan pasal 506. Dalam pasal 296 diatur tentang setiap orang yang sengaja mempermudah perbuatan cabul oleh orang lain sebagai pekerjaannya diancam dengan hukuman pidana paling lama 1(satu) tahun 4 (empat) bulan atau denda paling banyak 15.000.00 (lima belas ribu rupiah). Selanjutnya dalam pasal 506 mengatur bagi setiap orang yang menarik bayaran dari wanita yang dipekerjakan sebagai pelacur diancam dengan hukuman pidana penjara paling lama 1 (satu) tahun. Dapat diketahui bahwa hukuman pidana saat ini hanya mencakupkan / mengkategorikan prostitusi / pelacur sebagai suatu tindak pidana terhadap Germo dan Mucikari atau perantara dari si pekerja seks komersial. Melihat delik-delik kesusilaan yang telah diatur dalam KUHP, sungguh sangat sulit diberlakukan bagi Pekerja Seks Komersial (PSK) dan pengguna jasa Prostitusi (pelanggan seks komersial) yang datang mengunjunginya (Cesar Beccaria, 2011:21).

KUHP jika dikaji secara khusus maka tidak ada ketentuan pasal mengenai pengguna jasa prostitusi (pelanggan seks komersial) (E. Fernando., M. Manulang, 2016:33).Berdasarkan kajian kriminologi prostitusi seringkali disebut sebagai victimless crime atau kejahatan tanpa korban. Hampir tidak pernah ada pengguna jasa prostitusi yang tertangkap, setiap kali ada razia untuk penertiban prostitusi oleh penegak hukum. Itulah mengapa praktik prostitusi akan terus ada selama masih banyak pelanggan atau pengguna jasa prostitusi di indonesia (Cesare Beccaria). Seperti halnya teori ekonomi yaitu teori supply dan demand, bahwa tanpa adanya penawaran otomatis tidak akan ada permintaan begitupun sebaliknya yang terjadi.

apabila mengikuti hukum darisupply and demand (penawaran dan permintaan),maka selama permintaan kebutuhan seks kaum pria/wanita (pelanggan PSK) masih tinggi, maka penawaran akan selalu mengimbangi hal tersebut. Suplai pekerja seks komerisal atau praktik prostitusi/pelacur mustahil berhenti apabila hanya dibendung dari dihilir dengan menertibkan para perempuan/laki-laki pekerja seks dan menutup lokalisasi pelacuran tanpa digarap atau dirazia dihulunya dahulu, yaitu kemiskinan atau ekonomi yang buruk di perkotaan maupun di pedesaan yang menjadi pemasok atau penyedia para perempuan/laki-laki pekerja seks (Endang R. Setyaningsih-Mamahit, 2010:xii). Jadi, untuk memberantas praktik prostitusi di Indonesia baik mucikari, pengguna dan pekerja seks komersial haruslah sama-sama ditindak tegas berdasarkan asas keadilan.

Ketentuan hukum secara khusus yang mengatur tentang penggunaan jasa PSK (pelanggan) tidak diatur secara khusus dalam KUHP saat ini, namun apabila pelanggan atu pengguna jasa PSK tersebut telah mempunyai/memiliki pasangan resmi atau suami-istri yang sah (atas dasar pernikahan) dan kemudian pasangan dari suami atau istri tersebut mengadukan perbuatan pasangannya yang menggunakan jasa dari pekerja seks komersial, maka suami atau istri yang memakai jasa dari PSK tersebut dapat dijeratdengan menggunakan Pasal Perzinahan yang telah diatur dalam Pasal 284 KUHP (Simangungsong : 39). Meskipun pengguna jasa prostitusi (pelanggan PSK) yang telah memiliki 
ikatan perkawinan yang sah dapat dijerat dalam pasal tentang perzinahan, namun pengertian perzinahan dalam pasal 284 KUHP itu berbeda dengan pengertian pengguna jasa prostitusi, bahwa pengguna jassa prostitusi bisa saja tidak memiliki ikatan perkawinan sama sekali dan hubungan persetubuhan yang dilakukan tidak didasari oleh rasa suka sama suka namun orientasinya kepada komersial atau untuk memenuhi kebutuhan ekonomi.

Kenyataan mengenai belum adanya undang-undang yang mengatur secara khusus mengenai PSK di Indonesia memang benar adanya. Beberapa contoh kasus mengenai prostitusi (seks komersial) seperti di DKI Jakarta yang telah mengatur dalam menindak Pelanggan dan Pekerja Seks Komersial serta Mucikari berdasarkan pasal 42 ayat (2) Peraturan Daerah Nomor 8 Tahun 2007 tentang Kertiban Umum dan Peraturan Daerah Nomor 2 tahun 2015 tentang Penegakan Hukum Pidana Penanggulangan Pekerja Seks Komersial (PSK) di Kabupaten Demak.

Berdasarkan dari latar belakang yang telah diuraikan oleh penulis maka rumusan masalah yang akan diangkat penulis adalah sebagai berikut:

1. Bagaimana kategori pelaku dalam kegiatan seks komersial.

2. Bagaimanakah Penindakan Hukum Terhadap Pelanggan Dan Pekerja Seks Komersial.

\section{METODE PENELITIAN}

Metode yang digunakan dalam penelitian hukum ini adalah metode penelitian hukum Normatif dengan pendekatan Perundang-undangan, artinya menganalisis permasalahan hukum dengan melakukan pendekatan yang dapat dilihat dari peraturan-peraturan atau menelaah/menelitiperaturan perundangundang dan regulasi hukum yang berhubungan terhadap permasalahan hukum yang akan diangkat. (Dyah Ochtorina Susanti, A'an Efendi, 2014:110).Dalam penelitian hukum normatif ini, data dan sumber data yang diperlukan adalah bahan hukum primer yang berupa Perundangundangan sebagai sumber data utama disamping bahan hukum sekunder yang berupa bahan-bahan hukum pendukung dan juga bahan hukum tersier sebagai bahan penunjang terhadap bahan hukum primer dan sekunder.

a. Bahan hukum Primer yang berupa peraturan perundang-undangan yang berkaitan dengan Peraturan Hukum dalam menindak Pelanggan dan Pekerja Seks Komersial yang antara lain adalah sebagai berikut:

1. Undang-Undang Nomor 1 Tahun 1946 tentang Kitab UndangUndang Hukum Pidana (KUHP);

2. Undang-Undang Nomor 8 Tahun 1981 tentang Kitab Undang-Undang Hukum Acara Pidana (KUHAP);

3. Undang-Undang RI Nomor 21 tahun 2007 tentang Pemberatasan Tindak Pidana Perdagangan Orang;

4. Undang-Undang Nomor 19 Tahun 2016 tentang Perubahan Atas Undang-Undang Nomor 11 tahun 2008 tentang Informasi dan Transaksi Elektronik (ITE); dan

5. Undang-Undang Nomor 44 Tahun 2008 tentang Pornografi.

b. Bahan hukum sekunder yaitu bahan-bahan yang erat hubungannya dengan bahan hukum primer dan dapat menganalisis bahan hukum primer, antara lain berupa buku-buku yang berkaitan dengan judul penulis, hasil-hasil penelitian, karya tulis ilmiah, Koran dan lain sebagainya yang bisa dijadikan bahan untuk mengaanalisis dari bahan hukum primer.

c. Bahan hukum tersier merupakan sebagai bahan penunjang yang dapat memberikan informasi perihaldari bahan hukum primer dan sekunder yang digunakan. Bahan hukum tersier lebih dikenal juga sebagai bahan acuan atau bahan rujukan dibidang hukum yang berhubungan dengan penelitian yang sedang diteliti.

Dalam penulisan yang dibuat penulis membutuhkan bahan hukum yang 
memadai, sehingga masalah yang telah diketengahkan oleh penulis dapat terjawab dan selesai seperti yang diharapkan. Metode analisis dalam melakukan penelitian hukum yuridis normatif ini adalah dengan menggunakan metode analisis kualitatif. Hasil perolehan data dari analisis kualitatif ini adalah didapatkan/diperoleh dari berbagai sumber yang ada dengan cara menggunakan teknik pengumpulan data. Pengertiaan dari data kualitatif merupakan data yang tidak menggunakan angka-angka, akan tetapi berupa kata-kata, kalimat-kalimat, pernyataan-pertnyataan dan dokumendokumen yang penulis dapatkan dari beberapa sumber terpercaya yang dapat menunjang dalam penulisan skirpsi penulis.

\section{HASIL dan PEMBAHASAN}

\subsection{Kategori pelaku dalam kegiatan seks komersial}

Di dalam kegiatan seks komersial (prostitusi) ada beberapa kategori pelaku yang terlibat dalam kegiatan ini adalah sebagai berikut: (Caswanto, 2016:36)

1. Mucikari

DalamKamus Besar Bahasa Indonesia (KBBI) kata mucikari diartikan sebagai induk semang bagi perempuan yang melacurkan diri atau juga bisa disebut sebagai germo. Namun, dalam pemahaman masyarakat secara luas saat ini mucikari adalah orang yang berperan sebagai pengasuh, perantara dan "pemilik" PSK. Dalam kegiatan prostitusi biasanya pelanggan/pengguna jasa maupun PSK tidak berhubungan langsung namun melalui perantara pihak kegia yang disebut sebagai mucikari atau germo. Mucikari dalam hal ini sebagai penghubung antara kedua pihak ini dan akan mendapat komisi dari penerimaan PSK yang persentasenya dibagi berdasarkan perjanjian yang telah disepakati sebelumnya. Mucikari biasanya sangat dominan dalam mengatur hubungan ini, karena banyak PSK yang berhutang budi kepadanya. Banyak PSK yang diangkat dari kemiskinan oleh mucikari, walaupun dapat terjadi eksploitasi oleh mucikari kepada "anak asuhnya". Seperti ini pula mucikari dalam dunia prostitusi, mereka hanya penghubung antara pekerja seks komersial dengan mereka laki-laki hidung belang.

2. Pekerja Seks Komersial (PSK)

Pekerja Seks Komersial (PSK) adalah seseorang yang menjual jasanya untuk melakukan hubungan seksual demi mendapatkan uang atau disebut pelacur. PSK sebutan yang diperhalus dari sebutan pelacur, selain itu ada pula sebutan wanita tuna susila yang jug mengacu kepada layanan seks komersial. Praktek prostitusi dimanapun PSK inilah yang menjadi objek eksploitasi utama dari rantai praktek prostitusi.

3. Pengguna Jasa PSK (Pelanggan)

Pengguna Jasa PSK (pelanggan) adalah pihak yang merupakan sebagai pemeran dalam seks komersial dimana pengguna inilah yang menjadi titik bagaimana bisa transaksi prostitusi ini bisa terjadi.

Jenis prostitusi dapat dibagi menurut aktivitasnya, yaitu yang terdaftar dan terogranisir dan yang tidak terdaftar dalam penjabarannya adalah sebagai berikut: (Kartini Kartono, 2005:251)

1. Prostitusi terdaftar dan terorganisasi

Pelakunya atau pekerja seks komersial diawasi oleh Vice Control dari kepolisian, yang dibantu dan bekerja sama dengan jawatan sosial dan jawatan kesehatan. Pada umumnya mereka dilokalisasi dalam suatu daerah tertentu. Penghuninya secara periodik harus memeriksakan diri pada dokter atau petugas kesehatan dan mendapatkan suntikan serta pengobatan sebagai tindakan kesehatan dan keamanan umum.

Kegiatan ini biasanya sudah dilegalkan oleh Negaranya. Beberapa negara-negara di dunia yang melegalkan adanya aktivitas prostitusi adalah sebagai berikut: Selandia Baru, Austria, Bangladesh, Kolombia, Denmark, Ekuador, Jerman dan Yunani. Biasanya negaranegara tersebut menyediakan sebuah wilayah khusus yang dijadikan sebagai tempat prostitusi bagi Pekerja Seks Komersial(Http://Liputan6.Com Diakses Pada Hari Senin Tanggal 22 Juni 2019 Pukul 13:20 WIB).

2. Prostitusi tidak terdaftar 
Dalam kelompok ini ialah mereka yang melakukan prostitusi secara gelapgelapan dan liar, baik secara perorangan maupun dalam kelompok. Perbuatannya tidak terogranisir, tempatnya juga tidak tertentu. Bisa disembarang tempat, baik mencari mangsa sendiri, maupun melalui dari pihak ketiga dan melalui panggilan. Mereka tidak mencatatkan diri kepada yang berwajib. Sehingga kesehatannya sangat diragukan, karena belum tentu mereka itu mau memeriksakan kesehatannya kepada dokter. Biasanya kegiatan prostitusi ini dilarang atau tidak dilegalkan di Negaranya. Negara-negara yang melarang adanya kegiatan prostitusi adalah seperti Iran, Arab Saudi, malaysia dan termasuk Negara Indonesia. Meskipun demikian bukan berarti negara-negara yang melarang adanya kegiatan prostitusi bebas dari kegiatan tersebut karena kegiatan ini merupakan penyakit masyarakat yang susah di hilangkan karena sifatnya sembunyisembunyi.

PSK di Indonesia beraneka ragam, PSK mempunyai tingkatan-tingkatan opersional diataranya adalah: (Kartono Kartini, 2005:251)

1. Segmen kelas rendah, dimana PSK tidak terorganisir. Tarif pelayanan seks terendah yang ditawarkan dan biaya beroperasi dikawasan kumuh seperti halnya pasar, kuburan, taman-taman kota dan tempat lainnya yang sulit dijangkau, bahkan kadang-kadang berbahaya untuk dapat berhubungan dengan para PSK tersebut.

2. Segmen kelas menengah, dimana dalam hal tarif sudah lebih tinggi dan beberapa wisma menetapkan tarif harga pelayanan yang berlipat ganda jika dibawa keluar untuk di booking semalam.

3. Segmen kelas atas, pelanggan ini biasanya dari masyarakat dengan penghasilan yang relatif tinggi yang menggunakan night club sebagai ajang pertama untuk mengencani wanita panggilan atau menggunakan kontak khusus hanya untuk menerima pelanggan tersebut.

4. Segmen kelas tinggi, kebanyakan mereka dari kalangan artis televisi dan film serta wanita model. Super germo yang mengorganisasikan perdagangan wanita kelas atas ini.

Kegiatan prostitusi melalui modus operandi ditentukan oleh Pekerja Seks Komersial (PSK) yang apabila dia perempuan disebut Wanita Tuna Susila (WTS) dan apabila dia laki-laki disebut sebagai Gigolo. Ada yang berdiri di pinggiran jalan, ada yang duduk ditaman, ada yang mendapatkan tamu di bar, ada yang menunggu panggilan melalui telepon dan ada yang menempati lokasi tempat tertentu sebagai tempat praktik prostitusi. Dari berbagai cara WTS menawarkan pelayanan seksual, maka dapat diklasifikasikan cara melakukan kegiatan prostitusi. Cara melakukan kegiatan prostitusi yang dimaksud ialah dengan cara prostitusi jalanan, prostitusi panggilan, prostitusi rumah bordil dan prostitusi terselubung.

Pengklasifikasikan cara melakukan kegiatan prostitusi dipandang perlu untuk memudahkan pembinaan prostitusi baik pembinaan mental maupun spritual seperti pelayanan kesehatan. disamping itu juga memudahkan penulis untuk mengetahui bentuk-bentuk prostitusi yang adalah sebagai berikut: (Irma Pebrianti, 2015:21)

1. Prostitusi jalanan, pada umumnya pelayanan yang diberikan oleh jenis prostitusi semacam ini diberikan kepada laki-laki atau pelanggan yang penghasilannya rendah, misalnya buruh, abang becak, sopir dan pedagang kecil lainnya.

2. Prostitusi panggilan, prostitusi ini sering disebut call girl. Di Indonesia prostitusi semacam ini biasanya dilakukan melakui perantara seperti mucikari, manajer, mamas atau mami (panggilan untuk para mucikari) sekaligus operasi kegiatan seks tersebut di bawah pengawasan perantara tadi dan semakin berkembangnya teknologi biasanya cara memesan para PSK menggunakan media online.

3. Prostitusi rumah, prostitusi ini sering disebut juga dengan bordil/prostitusi atau rumah berdil yaitu praktik pelacuran, dimana pelacur dapat di jumpai di tempat-tempat tertentu, 
berupa rumah-rumah yang dinamakan dengan bordil yang disetiap bordil tersebut dimiliki oleh mucikari atau germo.

4. Prostitusi terselubung, sebagian kalangan menyebutnya dengan prostitusi terselubung karena mereka adanya di jalanan. Tentu saja ilegal dan bukan tidak pernah mereka ditertibkan oleh pihak berwajib. Prostitusi yang bukan hanya secara langsung antara penjual dan pembeli, tetapi bisa juga melalui perantara pihak ketiga seperti mucikari atau germo, prostitusi ini biasanya berkedok salon, spa dan bisa saja melalui internet. Sudah rahasia umum bahwa mereka tidak bekerja sendirian akan tetapi ada tangan-tangan kuat yang mengatur kerja mereka sehingga dapat memperlancar aktivitas yang akan mereka lakukan untuk mendapatkan pelanggan.

\subsection{Penindakan Hukum Pelanggan Dan Pekerja Seks Komersial}

Salah satu Pakar kriminolog dan hukum Kristoforus Kleden menyatakan bahwa belum ada pasal di dalam KUHP yang mengatur mengenai penegakan hukum pidana pengguna jasa PSK(pelanggan) dan pekerja seks komersial (PSK). Beliau merupakan pakar kriminolog dan hukum di Universitas 17 Agustus 1945 Surabaya (M.detik.com). Pemerintah di setiap daerah memiliki peraturan daerahnya masingmasing yang mengatur mengenai penegakan hukum pidana dan PSK akan tetapi tidak semua daerah memiliki peraturan tersebut misalnya Kabupaten Asahan.

\section{a. pertanggungjawaban pelanggan seks komersial}

Pengguna jasa PSK (pelanggan) tidak dapat dijerat dengan pasal yang ada di dalam KUHP di karenakan tidak ada pasal yang secara khusus mengatur ketentuan tersebut. Akan tetapi apabila pengguna jasa PSK tersebut telah mempunyai pasangan resmi atau merupakan suami istri yang pernikahannya sah, dan kemudian apabila salah satu pasangannya tersebut mengadukan perbuatan pasangannya yang memakai jasa PSK kepada penegak hukum, maka orang yang memakai jasa dari PSK tersebut dapat dijerat atau dikenakan dengan pasal Perzinahan yang diatur dalam Pasal 284. Dalam buku R. soesilo menyatakan bahwa agar masuk dalam pasal tersebut maka persetubuhan antara pengguna jasa PSK dan pekerja seks komersial harus atas dasar suka sama suka, tidak ada yang namanya paksaan dari salah satu pihak. Apabila tidak demikian maka pasal tersebut tidak dapat digunakan. (R. Soesilo, 209).

Walaupun di dalam KUHP tidak ada mengatur secara khusus mengenai pengguna jasa PSK (pelanggan) akan tetapi di beberapa daerah telah mengatur hal tersebut. Salah satu daerah yang mengatur mengenai prostitusi/pelacuran adalahPeraturan Daerah Provinsi DKI Jakarta Nomor 8 Tahun 2007 tentang Ketertiban Umum dalam Pasal 42 ayat (2) huruf c yang berbunyi: "Setiap orang dilarang:c. memakai jasa penjaja seks komersial.Setiap orang yang melanggar ketentuan hal ini akan dikenakan ancaman hukuman pidana kurungan paling singkat 20 (dua puluh) hari dan paling lama 90 (sembilan puluh) hari atau denda paling sedikit Rp. 500.000,00(lima ratus ribu rupiah) dan paling banyak $\mathrm{Rp}$. 30.000.000,00 (tiga puluh juta rupiah).

Selain daerah jakarta yang telah mengatur mengenai pengguna jasa PSK (pelanggan), ada juga Peraturan daerah lain yang telah mengatur mengenai prostitusi/pelacuran yang secara khususnya mengatur mengenai pengguna jasa dari pekerja seks komersial adalah Peraturan Daerah Kabupaten Pasuruan Nomor 3 Tahun 2017 Tentang Penanggulangan Pelacuran dalam pasal 14 huruf $b$ yang berbunyi: "setiap orang dilarang: $b$. menggunakan jasa pelacur". Apabila ketentuan ini dilanggar maka akan dikenakan dengan pasal 19 ayat (1) yang berbunyi: "pelanggaran terhadap ketentuan dalam pasal 14 diancam dengan pidana kurungan setinggi-tingginya 3 (tiga) bulan atau denda setinggi-setingginya Rp. 50.000.000,00 (lima puluh juta rupiah).Jadi, dalam menjeratpengguna jasa dari PSK tersebut harus menggunakan peraturan daerah masing-masing. 
Sehingga hal ini sebenarnya menjadi suatu kekosongan hukum bagi peraturan yang berlaku secara nasional yang dapat menjerat pelanggan pengguna jasa seks komersial secara langsung. Karena dalam peraturan nasional tidak ditemukan secara langsung dan pasti pasal yang dapat menjerat perbuatan pelanggan yang menggunakan jasa pekerja seks komersial. Maka dari itu sangat penting sekali suatu peraturan baru untuk menjerat secara pasti kepada pelanggan pengguna jasa pekerja seks komersial.

\section{b. pertanggungjawaban pekerja seks komersial}

Berdasarkan ketentuan hukum pidana atau KUHP tidak ditemukan pasal yang dapat diterapkan dalam menjeratpekerja seks komersial (PSK). Meskipun demikian, di beberapa Undangundang terdapat pasal maupun ketentuan yang berkaitan yang dapat menjerat pekerja seks komersial sebagai pelaku dari peristiwa hukum yang di timbulkannya. Peristiwa hukum yang diciptakan oleh pekerja seks komersial sebagaimana yang telah diatur dalam:

a. Undang-Undang Nomor 19 Tahun 2016 Tentang Perubahan Atas Undang-Undang Nomor 11 Tahun 2008 Tentang Informasi Dan Transaksi Elektronik (UU No. 11/2008)

Berdasarkan Pasal 27 ayat (1) Undang-UndangNomor 19 Tahun 2016 tentang perubahan atas UU No. 11/2008 tentang Informasi Transaksi Elektronik Setiap Orang dengan sengaja dan tanpa hak mendistribusikan dan/atau mentransmisikan dan/atau membuat dapat diaksesnya Informasi Elektronik dan/atau Dokumen Elektronik yang memiliki muatan yang melanggar kesusilaan. Hukuman bagi orang yang melanggar ketentuan dalam Pasal 27 ayat (1) UndangUndangNomor 19 Tahun 2016 tentangInformasi Transaksi Elektronik adalah sebagaimana diatur dalam Pasal 45 ayat (1) Undang-UndangNomor 19
Tahun 2016 tentangInformasi Transaksi Elektronik 19 Tahun 2016, yaitu Setiap Orang yang dengan sengaja dan tanpa hak mendistribusikandan/atau

mentransmisikan dan/atau membuat dapat diaksesnya Informasi Elektronik dan/atau Dokumen Elektronik yang memiliki muatan yang melanggar kesusilaan sebagaimana dimaksud dalam Pasal 27 ayat (1)dipidana dengan pidana penjara paling lama 6 (enam) tahun dan/atau denda paling banyak Rp. 1 miliar.

b. Peraturan Daerah

Peraturan Daerah Provinsi

DKI Jakarta Nomor 8 Tahun 2007

Tentang Ketertiban Umum dalam pasal 42 ayat (2) huruf $b$ yang berbunyi: "setiap orang dilarang: $b$. menjadi penjaja seks komersial". Orang yang melanggar ketentuan ini dikenakan ancaman pidana kurungan paling singkat 20 hari dan paling lama 90 hari atau denda paling sedikit Rp. 500.000,00 (lima ratus ribu rupiah) dan paling banyak Rp. 30.000.000,00 (tiga puluh juta rupiah) berdasarkan Pasal 61 ayat (2) Peraturan Daerah DKI 8/2007. Peraturan daerah lain yang mengatur tentang prostitusi yang khususnya mengatur mengenai pekerja seks komersial adalah Peraturan Daerah Kabupaten Pasuruan Nomor 3 Tahun 2017 Tentang Penanggulangan Pelacuran dalam pasal 14 huruf a yang berbunyi: "setiap orang dilarang: a. menjalankan pekerjaan dan/atau profesi sebagai pelacur.Ketentuan ini bila dilanggar akan dikenakan pasal 19 ayat (1) Peraturan Daerah Kabupaten Pasuruan Nomor 3 Tahun $2017 \quad$ Tentang Penanggulangan Pelacuran yang berbunyi: "pelanggaran terhadap ketentuan dalam pasal 14 diancam dengan pidana kurungan setinggitingginya 3 (tiga) bulan atau denda setinggi-setingginya Rp. 
50.000.000,00 (lima puluh juta rupiah).

Beberapa daerah lain juga mengatur tentang prostitusi melalui Peraturan Daerahnya yang antara lain adalah Surabaya, Kabupaten Kaloka Utara, Indramayu, Aceh dan lain sebagainya. Daerah yang telah memiliki peraturan mengenai prostitusi dapat menggunakan peraturan tersebut dalam menjerat para pelaku prostitusi. Namun, tidak semua daerah memiliki peraturan tentang pelacuran, contohnya daerah Kabupaten Asahan. Sehingga daerah yang tidak memiliki peraturan mengenai pelacuran tidak dapat menindak Pelanggan dan Pekerja Seks komersial (PSK).

c. pertanggungjawaban mucikari Beberapa ketentuan hukum yang dapat menjerat / pertanggungjawaban mucikari adalah sebagai berikut:

1. Kitab Undang-undang Hukum Pidana (KUHP)

Berdasarkan ketentuan hukum yang berlaku bagi mucikari yang turut serta mengambil bagian dengan terlibat dalam melancarkan kegiatan prostitusi yang dilakukan oleh pelanggan dan pekerja seks komersial. Sehingga beberapa pasal yang dapat menjerat secara tegas dan berat bagi mucikari yaitu dengan pasal 296 dan 506.

Pasal 506 KUHP diatur mengenai tindak pidana sebagai mucikari/germo yang mengambil keuntungan dari perbuatan melanggar kesusilaan atau perbuatan cabul yang dilakukan oleh seorang perempuan atau lakilaki terhadap seorang wanita (PSK), yang berbunyi: "Barang siapa menarik keuntungan dari perbuatan cabul seseorang wanita dan menjadikannya sebagai pelacur, diancam dengan pidana kurungan paling lama satu tahun".
2. Undang-Undang Nomor 35 Tahun 2014 tentang perlindunngan Anak

Undang-Undang Nomor 35 Tahun 2014 Tentang Perlindungan Anak mengatur mengenai bentuk tindak pidana eksploitasi seksual komersial pada anak dalam Pasal 15 dan Pasal 59 ayat (1) dan (2), pasal 15 berbunyi : "Setiap Anak berhak untuk memperoleh perlindungan dari: f. kejahatan seksual". Pasal 59 ayat (1) dan (2) berbunyi: ayat (1) Pemerintah, Pemerintah Daerah, dan lembaga negara lainnya berkewajiban dan bertanggung jawab untuk memberikan Perlindungan Khusus kepada Anak, dan ayat (2) Perlindungan Khusus kepada Anak sebagaimana dimaksud pada ayat (1) diberikan kepada: d. Anak yang dieksploitasi secara ekonomi dan/atau seksual; f. Anak yang menjadi korban pornografi; h. Anak korban penculikan, penjualan, dan/atau perdagangan; j. Anak korban kejahatan seksual; n. Anak dengan perilaku sosial menyimpang.

3. Undang-Undang Nomor 21 Tahun 2007 tentang Pemberantasan Tindak Pidana Perdagangan Orang

Undang-undang 21 Tahun 2007 Tentang Pemberantasan Tindak Pidana Perdagangan Orang (TPPO), merupakan upaya memberikan perlindungan hukum baik langsung, kepada korban dan/atau calon korban agar tidak menjadi korban dikemudian hari (Henny Nuraeny, 2013:237).Dalam Undang-undang Nomor 21 Tahun 2007 Tentang Pemberantasan Tindak Pidana Perdagangan Orang telah mengatur Larangan mengenai eksploitasi seksual berdasarkan Pasal 1 ayat (8) dan Pasal 2 ayat (1) dan (2). Pada Pasal 1 ayat (8) berbunyi: "Eksploitasi Seksual adalah segala bentuk pemanfaatan organ tubuh seksual atau organ 
tubuh lain dari korban untuk mendapatkan keuntungan, termasuk tetapi tidak terbatas pada semua kegiatan pelacuran dan percabulan".

Kemudian, pada Pasal 2 Undangundang Nomor 21 tahun 2007 menjelaskan ruang lingkup TPPO, yaitu:

(1) setiap orang yang melakukan perekrutan, pengangkutan, penampungan, pengiriman, pemindahan, atau penerimaan seseorang dengan ancaman kekerasan, penggunaan kekerasan, penculikan, penyekapan, pemalsuan, penipuan, penyalahgunaan kekuasaan atau posisi rentan, penjeratan utang atau memberi bayaran atau manfaat walaupun memperoleh persetujuan dari orang yang memegang kendali atas orang lain, untuk tujuan mengeksploitasi orang tersebut di wilayah Negara Republik Indonesia, dipidana dengan pidana paling lama 15 (lima belas) tahun pidana dan denda paling sedikit Rp. 120.000.000,00 (seratus dua puluh juta rupiah) dan paling banyak Rp. 600.000,00 (enam ratus juta rupiah); dan

(2) jika perbuatan sebagaimana dimaksud pada ayat (1) mengakibatkan orang tereksploitasi, maka pelaku dipidana dengan pidana yang sama sebagaimana dimaksud pada atat (1).

4. Undang-Undang Nomor 19 Tahun 2016 Tentang Perubahan Atas Undang-Undang Nomor 11 Tahun 2008 Tentang Informasi Dan Transaksi Elektronik (UU No. 11/2008)

Dalam Undang-Undang Nomor 11 Tahun 2008 Tentang Informasi dan Transaksi Elektronik (UU No. 11/2008) ada beberapa pasal yang mengatur mengenai tindak pidana dan eksploitasi seks komersial yaitu terdapat dalam pasal 27 ayat (1), pasal 45 ayat (1) dan pasal 52 ayat (1) jo 27 ayat (1). Pasal 27 ayat (1) yang berbunyi: "Setiap orang dengan sengaja dan tanpa hak mendistribusikan dan/atau mentransmisikan dan/atau membuat dapat diaksesnya Informasi dan Transaksi Elektronik dan/atau Dokumen elektronik yang memiliki muatan yang melanggar kesusilaan".

Dalam Pasal 45 ayat (1) berbunyi: "Setiap orang memenuhi unsur sebagaimana dimaksud dalam pasal 27 ayat (1), ayat (2), ayat (3)dan ayat (4) dipidana dengan pidana penjara paling lama 6 (enam) tahun dan/atau denda paling banyak Rp. 1.000.000.000,00 (satu milyar rupiah)". Pasal 52 ayat (1) jo. Pasal 27 ayat (1) berbunyi: "Dalam hal tindak pidana sebagaimana dimaksud dalam pasal 27 ayat (1) menyangkut kesusilaan atau eksploitasi seksual terhadap anak dikenakan pemberatan sepertiga dari pidana pokok".

5. Undang-Undang Nomor 44 tahun 2008 Tentang Pornografi (UU No. 44/2008)

UU No. 11/2008 Tentang Pornografi diatur dalam Pasal 30 jo. Pasal 4 ayat (2), pasal 4 ayat (2) huruf $\mathrm{c}$ undang-Undang 44 Tahun 2008 tentang Pornografi yang berbunyi: "Setiap orang dilarang menyediakan jasa Pornografi yang: mengeksploitasi atau memamerkan aktivitas seksual". Pasal 30 Undang-Undang Nomor 44 Tahun 2008 yang berbunyi: "Setiap orang yang menyediakan jasa pornografi sebagaimana dimaksud dalam Pasal 4 ayat (2) dipidana dengan pidana penjara paling singkat 6 (enam) bulan dan paling lama 6 (enam) tahun dan/atau pidana denda paling sedikit Rp 250.000.000,00 (dua ratus lima puluh juta rupiah) dan paling banyak Rp 3.000.000.000,00 (tiga miliar rupiah)". 
6. Peraturan Daerah

Peraturan Daerah Provinsi DKI Jakarta Nomor 8 Tahun 2007 Tentang Ketertiban Umum pasal 42 ayat (2) huruf a juga mengatur penindakan mucikari, yang berbunyi: "setiap orang dilarang: a. menyuruh, memfasilitasi, membujuk, memaksa orang lain untuk menjadi penjaja seks komersial".Orang yang melanggar ketentuan ini dikenakan ancaman pidana kurungan paling singkat 20 hari dan paling lama 90 hari atau denda paling sedikit Rp. 500.000,00 (lima ratus ribu rupiah) dan paling banyak Rp. 30.000.000,00 (tiga puluh juta rupiah) berdasarkan Pasal 61 ayat (2) Peraturan Daerah DKI 8/2007. Peraturan Daerah Provinsi DKI Jakarta Nomor 8 Tahun 2007 tentang Ketertiban Umum merupakan salah satu peraturan daerah yang dapat menjerat para pelaku prostitusi. Bahkan di dalam Peraturan Daerah tersebut juga melarang setiap orang atau badan menyediakan dan/atau menggunakan bangunan sebagai tempat berbuat asusila berdasarkan pasal 43 dan tindak pidananya diatur dalam pasal 61 ayat (3).Sedangkan, di dalam Peraturan Daerah Indramayu Nomor 4 Tahun 2001 tentang perubahan pertama peraturan kabupaten daerah tingkat II Indramayu Nomor 7 Tahun 1999 tentang prostitusi dalam Pasal 2 mengatur tantang larangan mendirikan tempat prostitusi dan ketentuan pidananya diatur dala oasal 9 ayat (1).

Dalam kasus germo Robby Abbas pada tahun 2015, yang menjajakan PSK di Jakarta, para korban, yang sebagian artis hiburan tanah air, juga hanya dimintai keterangan oleh polisi.Pengadilan Negeri Jakarta Selatan memjatuhkan hukuman pidana kepada Robby setahun empat bulan. Ganjaran tersebut polisi menerapkan sesuai ancaman maksimum Pasal 296 KUHP.

Berdasarkan dari pembahasan yang telah diuraikan oleh penulis diatas mengenai pengaturan hukum seks komersial dan pengaturan hukum dalam menindak pelanggan dan pekerja seks komersial, dengan hal tersebut maka pihak pemerintah atau pihak yang berwenang membuat Undang-Undang perlu melakukan tindakan dengan cara menambahkan Pasal-Pasal secara khusus dalam KUHP atau peraturan Khusus untuk mengatur Seks Komersial (Prostitusi). Perlu adanya kesepakatan Pakar Ahli Pidana Dan Sosiologi memberikan masukan untuk dilakukan kajiankajian terhadap pasal-pasal mengenai seks komersial dalam KUHP karna ini juga menyangkut soal moralitas sehingga ada perubahan yang memang di inginkan oleh seluruh elemen dalam pemberantasan tindak pidana seks komersial.

\section{KESIMPULAN DAN SARAN}

\subsection{Kesimpulan}

a. Kategori pelaku dalam kegiatan seks komersial adalah terdiri yang pertama dari mucikari sebagai pihak ketiga atau perantara antara pelanggan dan PSK, yang kedua adalah pelanggan atau pengguna jasa PSK dan yang ketiga adalah Pekerja Seks Komersial yang memberikan pelayanan jasa kepada pelanggannya.

b. Terhadap pelanggan dan pekerja seks komersial dapat diterapkan atau dapat dijerat dengan menggunakan Undang-Undang 21 tahun 2007 tentang Pemberantasan Tindak Pidana Perdagangan Orang. Jika korban masih di bawah umur, Undang-Undang Republik Indonesia Nomor 35 Tahun 2014 Tentang Perubahan Atas UndangUndang Nomor 23 Tahun 2002 Tentang Perlindungan Anak dapat diterapkan. Hal ini sering 
digunakan oleh pihak penegak hukum dalam menjerat mucikari yang turut terlibat dalam kegiatan prostitusi.Peraturan Daerah Provinsi DKI Jakarta Nomor 8 Tahun 2007 tentang Ketertiban Umum. Peraturan Daerah Nomor 3 Tahun $2017 \quad$ Tentang Penanggulangan Pelacuran. Serta Peraturan dimana hukum adat ataupun daerah tertentu yang dikasih hak istimewa untuk menyelenggarakan pengaturan hukum didaerah tersebut seperti pasal 25 ayat (2) Qanun Aceh No. 6 Tahun 2014Tentang Hukum Jinayat.

\subsection{Saran}

a. Perlunya pengaturan hukum yang berlaku secara nasional tanpa terkecuali dan berlaku kepada pelanggan, pekerja, mucikari ataupun siapa saja yang terlibat didalam kegiatan tersebut. Berkaitan dengan prostitusi sepanjang belum ada pengaturan hukum yang secara tegas mengatur prostitusi terkhusus bagi pekerja seks komersial serta pelanggan maka setiap daerah kabupaten/kota diharapkan memiliki pengaturan hukum tentang prostitusi demi melindungi manusia dari kesehatan serta moral.

b. Perlunya penindakan yang secara jelas dan tegas demi terwujud suatu keadilan dimana siapa saja yang terlibat didalam kegiatan prostitusi dapat ditindak secara tegas. Penindakan yang dilakukan seharusnya harus memberikan pembelajaran tentang bahayanya dapampak dari kegiatan seks komersial. Sehingga setiap yang terlibat dalam kegiatan prostitusi haruslah ditindak secara tegas, jelas dan tegas.

\section{DAFTAR PUSTAKA}

\section{Buku}

Pisani Elizabart, 2008, Kearifan Pelacur Kisah Gelap di Balik Bisnis Seks dan Narkoba, Serambi Imu Semesta, Jakarta.

Hull T., Sulistyaningsih, E., dan jones G.W., 1997, pelacuran di Indonesia Sejarah dan perkembangannya, Pustaka Sinar Harapan dan Foundation, Jakarta.

Tampi Butje, 2010, Kejahatan Kesusilaan dan Pelecehan Seksual dalam Hukum Pidana Indonesia, Karya Ilmiah Universitas Sam Ratulangi Fakultas Hukum Manado, Manado.

Kartini Kartono, 2005, Patologi Sosial, Raja Grafindo Press, Jakarta.

Godwin Joh, 2012, Pekerjaan Seks dan Hukum di Asia Pasifik Hukum HIV dan Hak Asasi Manusia dalam Konteks Pekerjaan Seks.

Beccaria Cesar, 2011, Perihal-Kejahatan dan Hukuman, Genta Publishing, Yogyakarta.

E. Fernando., M. Manulang, 2016 legisme Legalitas dan Kepastian Hukum, Pramada Media Group, Jakarta.

Setyaningsih Ending R -Mamahit, 2010 Perempuan-Perempuan kramat Tunggak, Kepustakaan Populer Gramedia, Jakarta.

Simangungsong., et.all, Analisis Yuridis Mengenai Pertanggungjawaban Pidana Pengguna Jasa Prostitusi dalam Perspektif KUHP.

Moeljatno, 2008, Asas-Asas Hukum Pidana, Rineka Cipta, Jakarta.

Hamzah Andi, 2008, KUHP Dan KUHAP Edisi Revisi 2008, Rineka Cipta, Jakarta.

Soesilo R., 1995, Kitab Undang-Undang Hukum Pidana (KUHP) Serta Komentar-Komentarnya Lengkap Pasal Demi Pasal, Politeia, Bogor.

Rizki Gerry Muhamad, 2017, KUHP Dan KUHAP, Permata Perss, Jakarta.

\section{Skripsi}

Caswanto, 2016, Tindak Pidana Prostitusi Yang Diusahakan Dan Disediakan 
Oleh Hotel Di Indramayu Dalam

Perspektif Hukum Pidana

Indonesia, Skripsi, Fakultas

Hukum, Universitas Pasundan.

Irma Pebrianti, 2015, Tinjauan

Kriminologis Terhadap Praktik

Prostitusi Di Kota Makassar,

Skripsi (Universitas Hasanuddin Makasar, Fakultas Hukum.

\section{Peraturan Perundang-Undangan}

Undang-Undang Nomor 1 Tahun 1946 tentang Kitab Undang-Undang Hukum Pidana.

Undang-Undang RI Nomor 21 Tahun 2007 Tentang Pemberantasan Tindak Pidana Perdagangan Orang.

Undang-UndangNomor 19 Tahun 2016 Tentang Perubahan Atas Nomor 11 Tahun 2008 Tentang Informasi Dan Transaksi Elektronik (ITE).

Undang-Undang Nomor 44 Tahun 2008 tentang Pornografi.

Peraturan Daerah Provinsi DKI Jakarta Nomor 8 Tahun 2007 tentang Ketertiban Umum

Peraturan Daerah Kabupaten Pasuruan Nomor 3 Tahun 2017 Tentang Penanggulangan Pelacuran.

Putusan Pengadilan Negeri Surabaya Nomor 2191/Pid.B/2014/PN.Sby.

\section{Internet}

Http://Liputan6.Com Diakses Pada Hari Senin Tanggal 22 Juni 2019 Pukul 13:20 WIB

M.detik.com, diakses pada hari selasa tanggal 23 juli 2019 pukul 16.05 